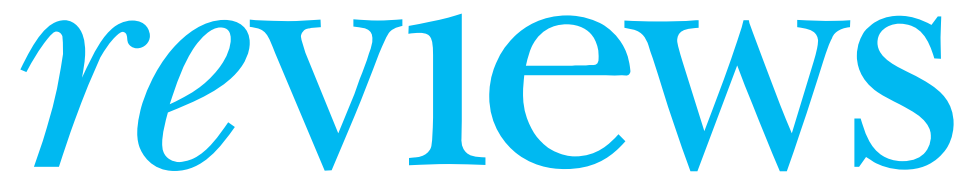

BOOKS • CD ROMS • ART •WEBSITES • MEDIA • PERSONAL VIEWS • SOUNDINGS

\section{Beneath the surface of stoicism}

\section{Media invocation of the "spirit of the Blitz" is a means of avoiding tragic human realities}

$\mathrm{T}$ he events of 7 July pose difficult, maybe unanswerable, questions. How should we respond? Why did they do it? How could they do it? How can we stop them? The government responds with heightened security, the need to police the state and our borders ever more closely, by introducing new antiterrorism legislation and strengthening our political alignment with the international "war on terror." But an event of this enormity requires a response from every single one of us. We cannot leave it to government alone. Besides, there are two seemingly unrelated issues arising from media coverage of the bombings that affect us all and demand our attention.

One is resurgence of the "spirit of the Blitz," which has figured prominently in reportage. It represents Londoners as brave, plucky individuals determined to carry on with their lives come what may. This image was reinforced by London's mayor, Ken Livingstone, Prime Minister Tony Blair, and the Queen. It was, of course, a stroke of fate that the national commemoration of $\mathrm{VE}$ and $\mathrm{VJ}$ day took place just three days after the bombs, but this celebration of Britishness was seized on by all. It was both script and balm; it told us how we should be responding and comforted us.

The other issue is very different. Throughout the coverage of the bombings, journalists and commentators have mirrored our sense of puzzlement and bewilderment at the actions of the young men who were implicated. Witness after witness was brought forward to say how outwardly "normal" the bombers appeared; how unremarkable they were. One was a teacher and a father, described as a gentle family man. Another was portrayed as a model student, a gentle giant who never came across as a fanatic. A third was playing cricket in the park with his friends the night before he travelled down to London. Most of the early accounts of the bombers' lives right up to the event concern

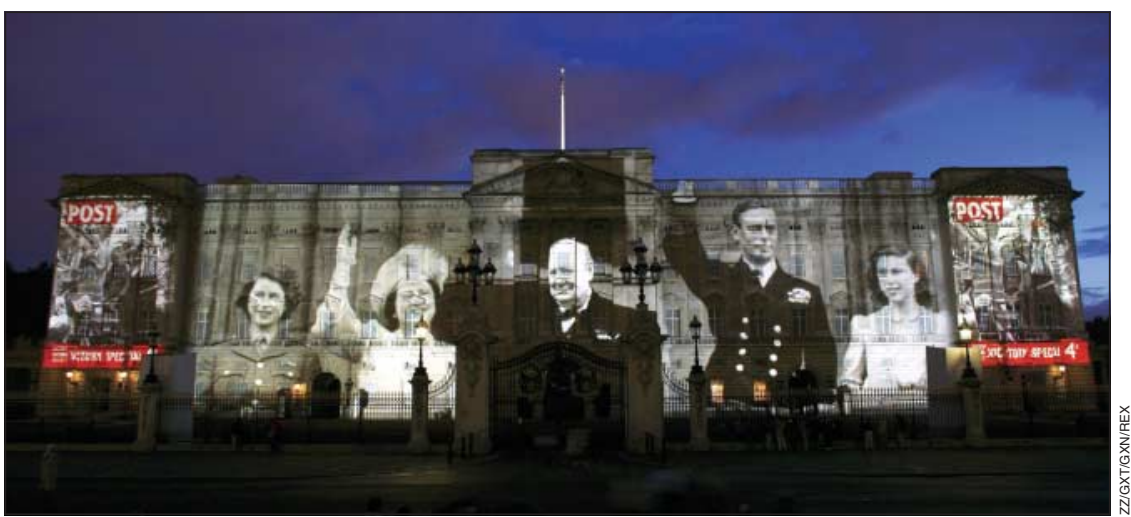

The VE/VJ day commemoration: an incantation to a bygone age

their ordinariness, their mundane external appearance. This echoes David Lodge's comment, in Consciousness and the Novel (London: Penguin, 2002) that none of the passengers on the hijacked planes on 11 September 2001 had any inkling of the terrorists' intentions before they boarded.

What emerges from these disparate themes is a separation of inner from outer, private from public, depth from surface, and mind from society. Ever since Descartes began our quest for certainty and truth by arguing that we should turn inwards ("I think therefore I am") our subjectivities have lain fractured on one side or another of these dualisms. The language we use for our inner worlds betrays this. Think of metaphors like putting on a brave face, keeping it under wraps, bottling it up.

These expressions pivot on the distinction between inner and outer, surface and depth. So, why should we be surprised if the men who murdered more than 50 fellow human beings appeared "ordinary"? Our preoccupation with interiority spawned a culture in which the persona must not divulge inner secrets, whether terrorists out to kill, or passengers on the tube living in fear of terror, daring not to break rank and reveal real selves. To do so would be to capitulate.

But there is a more troubled side to this separation of our inner and outer worlds. When we don the mask of sanity and hide our true feelings from each other, we also avoid having to face up to our moral complicity in the bombings. As long as we blindly stare at each other through eyes of fear, we do not have to ask awkward questions of ourselves and our leaders. Tony Blair claims that the London bombings had nothing to do with Britain's involvement in Iraq. Countless millions here, in Europe, in America, and in Asia disagree. As Guardian columnist Seumas Milne argued on 14 July, it is an insult to the memory of those who died to deny that there may be a link with Iraq. But Iraq is only a part of the problem; what about Palestine, or Afghanistan? Perhaps it is too painful right now to face up to the implications of our foreign policy.

After 11 September 2001 Ian McEwan wrote: "If the hijackers had been able to imagine themselves into the thoughts and feelings of the passengers, they would have been unable to proceed ... Imagining what it is like to be someone other than yourself is at the core of our humanity. It is the essence of compassion and the beginning of morality" (Guardian, 13 September 2001).

If this applies to terrorists, which it must, then it must surely apply to us all. Our lives continue. We have the Olympics to look forward to. Meanwhile, we travel by tube and bus, indifferent to our pain and fear. Good! We soldier on; we brush it under the carpet. And the cost? The cost is that we do not stop to think what it is like to be the parents of the 10000 young Muslims massacred in Srebrenice.

The media reflect the way we see ourselves; they shape our subjectivity. The "spirit of the Blitz" is nothing more than a whisper, an incantation to a bygone age in which we knew with certainty where the threat lay. It is comforting, at times of national crisis, to retreat behind cricket and warm beer notions of Englishness, but in doing so not only do we avoid our real feelings, we also avoid other tragic human realities that challenge our view of the world. Terrorism will only end when we can honestly look at each other with piteous recognition.

Philip Thomas senior research fellow, Centre for Citizenship and Community Mental Health, School of Health Studies, University of Bradford p.thomas@bradford.ac.uk 


\section{Health Care Systems in Transition: Cyprus}

Christina Golna, Panos Pashardes, Sara Allin, Mamas Theodorou, Sherry Merkur, Elias Mossialos, Ed Sara Allin, Elias Mossialos

European Observatory on Health Systems and Policies, pp 117 Vol 6, № 5, 2004

ISSN 10209077

www.euro.who.int/Document/E85255.pdf

Rating: $\star \star \star$ is

\section{Health Care Systems in Transition: Germany}

Reinhard Busse, Annette Riesberg

European Observatory on Health Systems and Policies, pp 232

Vol 6, No 9, 2004

ISSN 10209077

www.euro.who.int/Document/E85472.pdf

Rating: $\star \star \star \star ⿱ 乛 龰$

\section{Health Care Systems in Transition: Slovakia}

Svätopluk Hlavaèka, Róbert Wágner, Annette Riesberg

European Observatory on Health Systems and Policies, pp 116 Vol 6, No 10, 2004

ISSN 10209077

www.euro.who.int/Document/E85396.pdf

Rating: $\star \star \star \succsim$

\section{Health Care Systems in Transition: Estonia}

Maris Jesse, Jarno Habicht, Ain Aaviksoo, Agris Koppel, Alar Irs, Sarah ThomsonEd Sarah Thomson

European Observatory on Health Systems and Policies, pp 140 Vol 6, No 11, 2004

ISSN 10209077

www.euro.who.int/Document/E85516.pdf

Rating: $\star \star \star \star ぇ$

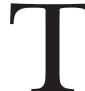
he European Union is here to stay, whatever the outcome of referendums, budget battles, or the Eurovision song contest. It has and will have a profound impact on health issues, even in the United Kingdom, where "Europe" is often talked about as though it were somewhere else. Health, and increasingly health care, is no respecter of frontiers; its determinants range from imported diseases to health tourism, from drug trafficking to the migration of doctors.

The study of health and health care in neighbouring countries is therefore increasingly important. We may consult, employ, or work alongside their professionals; treat their patients or send them ours; and encounter illnesses contracted there. Willingly or not, we may participate in experiments launched after fact finding mis-

Items reviewed are rated on a 4 star scale (4=excellent)
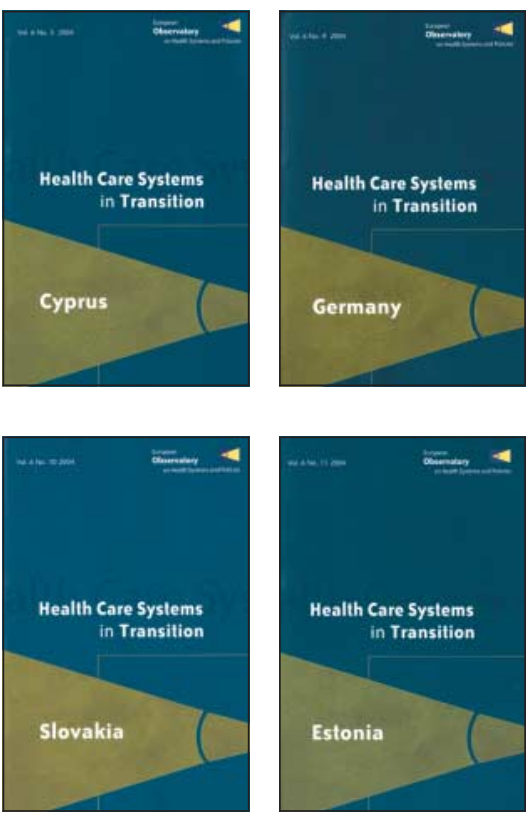

sions to foreign capitals-most notoriously the former health secretary Alan Milburn's Madrid visit that inspired foundation hospitals. The search for different solutions drives us to compare and contrast, and scrutiny of other health systems prompts critical appraisal of our own.

The European Observatory on Health Systems and Policies, a partnership between the World Health Organization, six European governments, and other leading institutions, is an invaluable resource. From modest beginnings in the early 1990 s, as the WHO European office struggled to understand and influence the aftermath of the collapse of communism, the observatory is playing an

For all this plethora of information we don't really know what works expanding role in gathering, analysing, and disseminating information and ideas. Its most visible and handy product is a series of country profiles, Health Care Systems in Transition (HiTs for short).

Each profile uses the same template to combine facts, figures, and analysis and is occasionally updated by a team combining native and foreign expertise. The latest batch comprises the third updates on Estonia and Slovakia, the second on Germany, and a first edition on Cyprus-so almost every European country is now covered, as well as Australia, Canada, and New Zealand. The authors are the first to admit that much of the information is patchy and of variable quality, reflecting the often parlous state of official data. There may be big discrepancies (for example, the World Bank puts infant mortality in 2002 in Estonia at 10 per 1000 live births while the government puts it at 5.7).

Designed primarily for analysts of financing and resource allocation, with most interpretation left to the reader, the profiles make dry reading; only those with a forensic interest in social insurance and reimbursement will read them from cover to cover. Nevertheless, assisted by a conclusion that ventures to make a judgment, they give a good flavour of the current state.

The latest profiles of three new EU members (combined population 7.5 million) and mighty Germany ( 82.5 million) provide ample opportunity to compare, contrast, and assess EU trends. Slovakia has made the least headway in outgrowing the negative aspects of its communist legacy; health sector reforms have failed to contain costs or improve effectiveness, and it faces severe organisational and financial difficulties. Former Soviet colony Estonia is slowly improving, with better health and health system indicators than other former Soviet republics and financial sustainability in the healthcare sector, despite spending less than the EU average share of gross domestic product (GDP) on health $(5.5 \%)$. Cyprus, once a British colony, does well on some indicators, but many of its citizens are overweight and smoke too much, while over half its health spend goes on private medicine.

According to what is inevitably the most hefty profile, at 230 pages, Germany's health system works well in terms of free choice, ready access, high staffing levels, and technology, with waiting lists and rationing virtually unknown-popular with the public. It has helped reduce health inequalities between the former East and West and contributed to a remarkable rise in life expectancy of the "Ossies." But before we rush to emulate its 300-odd statutory health insurance schemes, complex funding mix, and high percentage of GDP spend on health (double Estonia's, at $10.9 \%)$, beware: in the 2000 WHO global league table, Germany ranked only 25th on health system performance, the efficiency of goal attainment to money spent.

And there's the rub: for all this plethora of information we don't really know what works. "There is increasing doubt whether the high level of spending on health translates into good quality care and cost-efficient use of resources," the Germany HiT concludes. The four reports leave an abiding impression that, unfortunately for patients and staff, healthcare reform is a huge laboratory where experts advocate their pet solutions on a shaky evidence base, bending the ears of politicians who use that evidence as a drunk uses a lamppost, for support rather than illumination. Next time you go to "Europe," download the profile free from www.observatory.dk to stick in your bag along with your Lonely Planet guidebook, and you'll have plenty to think about on the plane.

Jane Salvage international health consultant 


\section{Transformation of minds and souls}

A

$\mathrm{t}$ a time of much transformation of health systems worldwide, I offer this story of transformation of health professionals' minds and souls in the former Yugoslavia. In socialist Yugoslavia the standards and skills of doctors conformed to worldwide standards, although few had an international reputation. The main health indicators in Yugoslavia were in line with most European countries, and in some clinical fields our results even exceeded those of major centres worldwide. Most doctors were paid enough by the government to live comfortably, and only minor, insignificant corruption existed in the hospitals. In short, medical doctors had secure jobs, were respected in their communities, and had a relatively privileged lifestyle.

When the 1992-5 war started many health professionals fled the country. In Bosnia-Herzegovina the number of people employed in the health sector fell from about 19000 in 1991 to about 12000 in 1996. It was not easy to become a wartime doctor overnight. My medical education focused on teaching me the skills to be a researcher, and manager. In just a few days I found myself having to perform in completely new roles: as hero, negotiator, expert in logistics, and guardian of principles.

With war the rules of civil society were destroyed. Doctors were no longer automatically considered people of authority; instead authority and power were held by anyone with a gun. Under shelling and sniper fire we rapidly became aware of our own mortality. We also faced danger inside the hospital building: of enraged, drunk, or drugged fighters wandering out of control through the hospital (even into operating theatres). Frightened, we had two choices: to retreat to lifelong learner, clinician, educator,

the shelters or to take on the role of hero, pretending that we, in contrast to all around us, were fearless. When the gunmen shouted at us, promising hell, we did not keep quietgaining respect was the only way to ensure a "normal" working situation.

\section{Some doctors became politicians, war lords, and even war criminals}

To illustrate: just before the war began I was called to the hospital shortly before midnight to attend two patients with bullets in their heads. When I arrived I found both of them comatose and a third man, with arm and leg injuries, surrounded like dying royalty by eight armed henchmen, who clearly had little trust in doctors and demanded to supervise the treatment. In the following weeks I would learn to distinguish these men, but that night I was still blessed by ignorance. The wounded man would soon become "the Wolf"- a national legend and a general of the "special forces." I pretended to be enraged and asked the henchmen to leave the hospital. They pointed their guns at me and said that I would be the one to leave not only the hospital but "this world." Standing up to them, I replied, "OK, then you perform the surgery." Their leader gave a single wink, and I led the men out, like a group of misbehaving schoolboys, to the awe of the staff and hospital security guards. I went to the operating theatre, did what I could, and at around 4 am decided to make a last round. The staff room for the hospital's security guards was filled with 20 armed men, smoking and whispering. "What are all those people doing here? Get them out!" I ordered. "We can't control

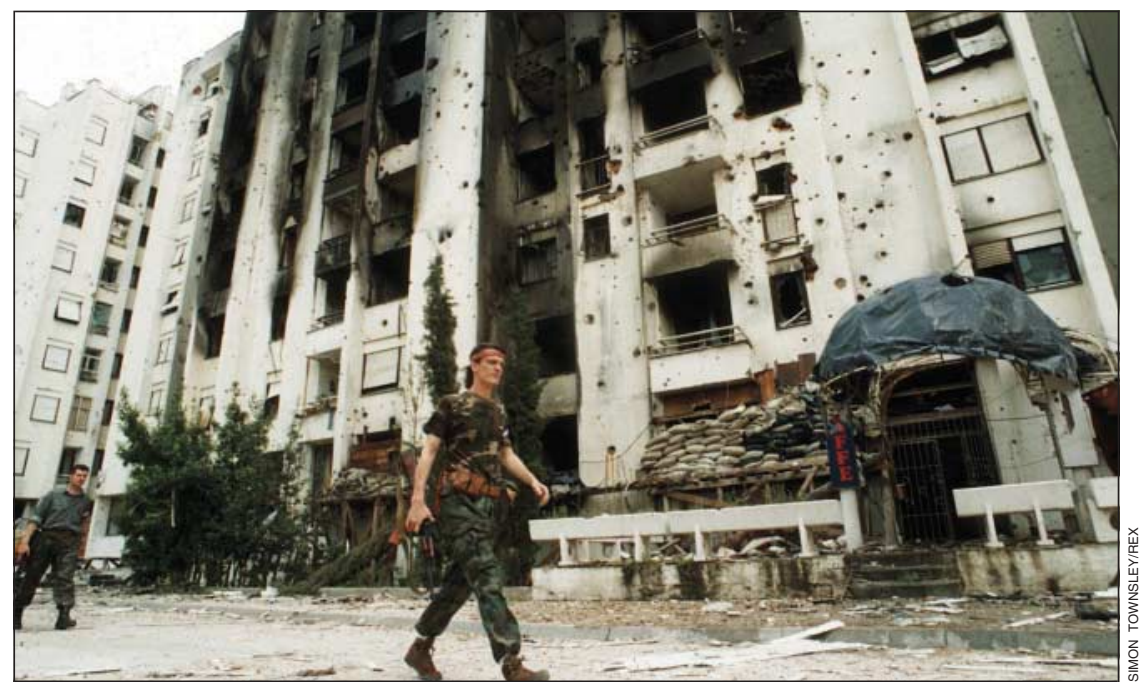

When the war started doctors were without reliable power, water, heating, drugs, and food them," the guards replied. "There are another hundred surrounding the hospital. They will listen only to you." Like it or not, I had been assigned the role of hero.

Sometimes the role of hero didn't work, and we had to cast ourselves as negotiators in a game where argument was usually pointless. If I needed oil for a generator so an urgent operation could be done, and the war lord needed the same oil to drive his stolen car, my argument was unlikely to prevail. However, if the leader of a paramilitary unit decided to take away a wounded patient for torture and execution, our long, hard negotiations were, I am proud to say, almost always successful. But we, the negotiators, were left with a burden-I still have nightmares, even today, 10 years after the war.

Normally the smooth functioning of a hospital relies on dozens of people and services working in the background. When the war started our infrastructure broke down and we found ourselves without reliable power, water, heating, drugs and other supplies, food, and means of transportation, though still responsible for hundreds of wounded soldiers and civilians, whom we were unable to evacuate. It took no more then a few days for us to understand that unless we took on the role of logistics experts we would have to close the shop. How we managed this role is a long and sometimes funny story but is beyond the scope of this piece.

Finally, as doctors we cherish the ancient values of our profession, as condensed in the Hippocratic Oath. Sadly, some of our doctors became politicians, war lords, and even war criminals. Others, however, were prepared to sacrifice their wellbeing and even their lives to protect their integrity and professional standards. In every single moment of every day we had, in the role of guardian, to ponder carefully each word and act, being permanently in the spotlight and a role model for all our team members.

It is hard to believe how, since the war, self interest has grown among the "heroes in white," as the media used to call us. Most doctors have accepted the philosophy of minimal service for maximum gain. A large number of private doctors' practices (some legal but most illegal) have been opened, charging fees irrespective of the wealth, or lack of it, of their patient populations. Even professional solidarity has died, their colleagues becoming just other "customers." And this is yet another story to be told-much dirtier than the wartime one.

Vladimir J Simunovic professor of neurosurgery, School of Medicine, Mostar University, Mostar Bosnia-Herzegovina vsimunov@public.srce.hr 


\section{Projectitis? Supporting health reform}

I

n 1992 I visited Russia as the Royal College of General Practitioners' St Petersburg fellow. The next year I hosted two Russian doctors in England. Since this exchange I have visited St Petersburg at least once a year and been asked to work on development projects in several countries of the former Eastern bloc. A few of these projects have led to real change; others achieved their objectives but left a vacuum when they finished; and a few collapsed halfway through. Each country and project is different, and practice cannot be truly evidence based. But lessons can be learnt about how we help other countries develop their health services.

The brand of Western democracy that was on offer after the fall of Communism was strongly influenced by the prevailing economic philosophy. An important legacy of this philosophy is development through "projects"-defined programmes of work with clear objectives and of fixed scope and duration (often one or two years, rarely more than four). Typically they are funded through agencies such as the World Bank, the European Union's programme of technical aid to the Commonwealth of Independent States (TACIS), or the UK Department for International Development. A small industry in selling development expertise has grown up, with organisations tendering competitively for contracts often worth several millions of dollars or euros. These organisations manage the project, employing experts like me to deliver the technical assistance. This approach has major limitations in supporting the sustainable development of health care and in encouraging expertise to "cascade" through the post-communist world.

Communist health services tended to be top heavy, with too much badly functioning technology in secondary care and an inadequate skills base in primary care. Too many doctors were paid badly to practise tiny specialties after a short and narrow postgraduate training; access to research findings and evidence based ideas was limited; and there was too much reliance on professorial authority and ideas learnt many years before. I have met some doctors I would be happy to have treat me or my family, but I have also come across neurologists who could not elicit reflexes, ear, nose, and throat surgeons who treated tonsillitis by scrapping the pus off the tonsils, and paediatricians happy to give tetracycline to children for urinary tract infections but rejecting the use of steroids for asthma.

There is a limit to how fast sclerotic organisations can change. Political turmoileven positive events like the recent "orange revolution" in Ukraine-can halt progress for weeks or months. The attraction of well funded international projects for key local stakeholders is considerable. This does not necessarily mean corruption (though that certainly exists), but it does include lucrative consultancies and foreign study tours and conferences and the kudos that they bring. Effective reform comes well down the list of incentives.

I had been visiting Russia for more than seven years before I heard anyone tentatively acknowledge that successful healthcare reform might mean redundant doctors. Yet doctors realise this; and unless acceptable exit strategies are offered they have a powerful incentive to resist reform

Personal relationships and knowledge of local political, legal, and institutional frameworks are often important to successful outcomes. However, by the time these have been built up projects are often almost over. Part of a successful project is often defining the next step, but having done that development organisations are often barred by anticorruption procedures from taking that step. Many countries have common needs, but no funding system exists to develop tools that could be used in several countries. Indeed the competitive "market" in technical assistance discourages sharing of experience and expertise.

So what should be done? Health care cannot be reformed piecemeal. Model practices and pilot initiatives in one area of the system may lead to envy and antagonism rather than be catalysts for change. Offering expensive training to high fliers may mean they escape to a new country rather than lead reform.

Funding organisations and development consultancies need to be better coordinated and to work in several countries, enabling an evidence base of experience to be built up and tools developed that can be used across several countries. Often the political will to tackle reform seriously will be lacking. Not all countries are yet ready to move to a health service with democratic values. Perhaps the most we can do is to support the development of long term partnerships and educational programmes that encourage local experts who are open to change.

Peter D Toon general practitioner, Canterbury petertoon@aol.com

Competing interests: PDT has received several small grants from the UK Department for International Development and has been paid as a consultant on projects funded by the the department, the World Bank, and TACIS.
SOUNDINGS

\section{Uncompassionate} care

Two days after returning from a tropical country, a woman doctor awoke in the middle of the night with shaking chills and diarrhoea.

She calls for an ambulance. She waits in the emergency room of a prestigious teaching hospital for six hours and is admitted to the ward. They find Escherichia coli in the blood and administer a wide spectrum antibiotic (piperacillin-tazobactam). But the fever and diarrhoea continue unabated for the next three days. The patient and her spouse are becoming anxious. They have seen the attending physician only once, briefly, on the day of admission. The residents work in shifts, are constantly rushing around, and nobody can shed light on the problem.

A computed tomograph is now ordered. It shows a complex mass in the left iliac fossa. Is it an abscess or cancer? The patient, a surgeon herself, thinks it is abscess and should be explored and drained. The internist in charge is nowhere to be seen.

She is next transferred to a surgical ward. New doctors, new history, and exams-all the previous doctors have vanished. It is Friday. A taciturn young surgeon visits but says little. Antibiotics are continued. The family is becoming desperate.

Comes the weekend. Everything slows to a standstill-that is until Sunday night, when the patient has severe abdominal pain and undergoes emergency surgery at $2 \mathrm{am}$. A benign small bowel tumour is removed; because of peritonitis she is left for three months with a colostomy, also an iliostomy that is highly awkward to manage. Eventually everything is restored to normal.

It is unfair to second guess the management of this case without at least seeing the $\mathrm{x}$ rays. Some seasoned surgeons have suggested that they might have intervened earlier; have wondered why both a colostomy and iliostomy were necessary; and implied that academia does not lend itself to surgeons becoming highly experienced. And yet nobody's reputation would have been harmed if the doctors of that prestigious institution had spared a few minutes of their valuable time to talk to the patient and her family, listen, explain, and assuage their anxieties.

George Dunea attending physician, Cook County Hospital, Chicago, USA 